See discussions, stats, and author profiles for this publication at: https://www.researchgate.net/publication/325725270

Reframing urban street culture: Towards a dynamic and heuristic process model

Article · June 2018

DOI: $10.1016 /$ j.ccs.2018.05.003

1 author:

Jeffrey lan Ross

University of Baltimore

149 PUBLICATIONS 1,296 CITATIONS

SEE PROFILE

Some of the authors of this publication are also working on these related projects:

Project Understanding Street Culture View project

Project The Popular Culture of Corrections View project 


\title{
Reframing urban street culture: Towards a dynamic and heuristic process model
}

\author{
Jeffrey Ian Ross ${ }^{\mathrm{a}, \mathrm{b}, *}$ \\ a School of Criminal Justice, University of Baltimore, 1420 North Charles St., Baltimore, MD, United States \\ ${ }^{\mathrm{b}}$ Visiting Professor, Kriminologie, Kriminalpolitik, Polizeiwissenschaft, Ruhr-Universität Bochum, Germany
}

\begin{abstract}
A B S T R A C T
The fields of criminology/criminal justice have periodically used the term and concept of urban street culture to explain selected types of street crime and gang behavior. This article argues that this characterization of street culture is too narrow, and that the concept has wider applicability to urban processes, including urban studies, urban anthropology, and urban geography. In so doing, this article briefly reviews the concept of street culture, including relevant research on this topic, argues that a dynamic process model is necessary, and then proposes one that is heuristic and dynamic in nature. The model consists of five major components that explain street culture, including street capital, competing cultural influences, mass media/cultural industries, social media, and street crime. These elements account for the complexity of street culture, and are assembled in a manner that allows for future hypothesis testing and theory building.
\end{abstract}

\section{Introduction ${ }^{1}$}

The streets of our inner cities are deceptively complex places. Some are primarily located in residential areas, others have businesses located along them, and many others run through mixed-use neighborhoods. In order to get from one place to another, people use the streets to drive on, the sidewalks adjoining them to walk on, and the back alleys to gain access to the structures that exist on the streets (e.g., Goffman, 1956). But what I have described here is a structural and functional arrangement.

Ever since humans decided to live and work in cities, streets have increasingly become the setting for numerous activities (e.g., transportation, commerce, socialization, etc.), including acting as a source of inspiration for many different expressions of culture. Culture consists of both visible components, like behaviors and clothing, and less noticeable aspects, like language and attitudes. Part of this dynamic are people's (both participants and observers) unique interactions in urban contexts (Abrahamson, 1974; Goffman, 1967; Jacobs, 1961; Wirth, 1938), including but not limited to their relationship with the street.

Throughout the 24 hour lifecycle of the street, numerous individuals interact with this built environment. This requires adaptations that people and organizations make to deal with the challenges of this environment. Streets can be understood on different levels. They can be interpreted from geospatial, economic (e.g., business), usability, and also cultural approaches. ${ }^{2}$ It is important to understand that the street is not just the barrio, ghetto, hood, inner city, slums, or disadvantaged or impoverished areas of big cities. ${ }^{3}$ Streets are part of every big city where residents work, live, and conduct commerce.

Interactions on the street are mediated by a number of important factors (Goffman, 1967). One of the most critical components is the physical place/urban space. Knowledge regarding this context is typically embedded in the subjects and fields of architecture, and urban planning and theory (Campbell \& Fainstein, 2011; Fainstein \& Campbell, 2011). Although these broad perspectives are important, they are relatively silent on the meaning and effects of the street. Short of the obvious observations, such as streets being dominant venues for transportation, we need to look to other kinds of explanations and contextual factors, such as culture. One of the most important aspects is the culture that emanates from the street, or more specifically urban street culture, or street culture for short. ${ }^{4}$

\footnotetext{
* School of Criminal Justice, University of Baltimore, 1420 North Charles St., Baltimore, MD, United States.

E-mail address: jross@ubalt.edu.

${ }^{1}$ An earlier version of this paper was delivered at Institut für interdisziplinäre Konflikt- und Gewaltforschung (IKG), University of Bielefeld, June $20,2017$.

${ }^{2}$ See, for example, Matthews (2003), who discusses the street as a transitional space for children.

${ }^{3}$ For an early discussion that attempts to distinguish between the ghetto and slum, see for example, Lind (1930). See also Lewis (1968) for a depiction of "the slum." And Wirth (1928/ 1997) for a description of "the ghetto."

${ }^{4}$ The terms urban street culture and street culture are used interchangeably throughout this paper.
} 
Before continuing, however, it might be helpful to define the term. Achieving a consistent definition of street culture is difficult. ${ }^{5}$ One of the reasons for this state of affairs is the frequent reliance in contemporary popular culture on the phrase street culture. ${ }^{6}$

A handful of scholars have attempted to create a definition. Anderson (1999/2000), for example, defines street culture as "a set of informal rules governing interpersonal public behavior, particularly violence... [which provide] a rationale allowing those who are inclined to aggression to precipitate violent encounters in an approved way" (p. 33). Anderson privileges the notion of violence and behavior in his definition of street culture. ${ }^{7}$ Alternatively, Bourgois (2003) argues that street culture "is a complex and conflictual web of beliefs, symbols, modes of interaction, values and ideologies that have emerged in the opposition to exclusion from mainstream society" (p. 8)..$^{8}$ Bourgois emphasizes the oppositional nature of the street culture concept. Finally, Ilan (2015) defines street culture as the "values, dispositions practices and styles associated with particular sections of disadvantaged urban populations" (p. 8; p. 169). In terms of its causation, Ilan states that street culture is a "product of social, economic and cultural exclusion .... a process of attempts to remain viable, thriving and include within a specific street milieu" (p. 3). This definition implies that street culture is primarily a behavior of poor and marginalized people.

Although these definitions are an important start to understanding street culture, they are relatively narrow. I prefer a definition that builds on Anderson, Bourgois, and Ilan. Thus, I define street culture as the beliefs, dispositions, ideologies, informal rules, practices, styles, symbols, and values associated with, adopted by, and engaged in by individuals and organizations that spend a disproportionate amount of time on the streets of large urban centers. ${ }^{9}$ In many respects street culture embodies Bourdieu's notion of habitus (1977), which explains how people perceive the world around them and how they react, including their body postures. ${ }^{10}$ Street culture is also a form of communication, not only among individuals inside that culture but also to outsiders. It can be simultaneously a defensive posture and a means for group solidarity.

Another point worth considering is the following. Since the concept of street culture originated in the United States and was initially applied to American settings, it would be tempting to assume that both the phenomenon and study of street culture is a uniquely American phenomenon. This interpretation, however would be shortsighted. In reality, the term and concept of street culture has also been applied to research settings including, but not limited to, Canada (Baron, 1989), Norway (Sandberg \& Pedersen, 2009), Germany (Zdun, 2008), the United Kingdom (Pavis \& Cunningham-Burley, 1999), the continent of Africa (Biaya, 2005), and colonial Singapore (Savage, 1992). ${ }^{11}$

\section{Why is understanding street culture important?}

Street culture is important for many respects. Most relevant, street

\footnotetext{
${ }^{5}$ Some scholars use the term street culture in the titles of their articles or mention this concept in passing in the body of their work, but fail to define it at all.

${ }^{6}$ For example, numerous fashion magazines invoke "street culture" as a source of inspiration and expression for certain types of fashion

${ }^{7}$ Although Anderson uses the concept of street culture in his seminal texts, Street Wise (2010) and Code of the Streets (1990/2013), I have chosen to use the one he utilizes in Street Wise (2010).

${ }^{8}$ Sandberg (2008a) characterizes Bourgois' interpretation "as an alternative forum for autonomous personal dignity. It is a lifestyle of violence, substance abuse and internalized rage, with drug dealing as the material base" (p. 603).

${ }^{9}$ Clarification of this definition is not meant to be a synopsis of Anderson's, Bourgois', or Ilan's characterizations of street culture. I have simply cherry-picked terms from these scholars definitions to create my own. I am also agnostic with respect to "the centrality of poor/marginalized people's violent behavior and oppositional culture."

${ }^{10}$ Although tempting, I do not believe that an in-depth discussion of Bourdieu would contribute to a better understanding of the main argument that I present, but would instead take the discussion off in a tangential direction.

${ }^{11}$ It is not my goal to review these studies as I believe this would take this paper off in a tangent that would be distracting to the central thesis and theme of the paper.
}

culture:

A. Is alluded to in many classic studies of urban gangs and juvenile delinquency, staples of the fields of criminology, criminal justice, and sociology. Embedded in this literature is a respectable body of scholarly work which mentions, either in passing or in greater detail, the street culture concept.

B. Impacts a large percentage of the population of most countries. Since World War Two, if not earlier, the greatest concentrations of populations in most countries throughout the world have been in urban cities. This is as true for the United States as it is for the People's Republic of China.

C. Influences art, graffiti/street art (Ferrell, 1996; Ross, 2016), clothing/fashion (Polhemus, 2010), lifestyles, and elements of popular culture, ${ }^{12}$ more specifically being a source of ideas for cultural commodities that are bought, sold, listened to, viewed, etc. (e.g., music, food, dance, music, literature, etc.). ${ }^{13}$ The themes of the street and the cultures that embody it are readily visible in numerous aspect of merchandise that is offered for sale. Otherwise, street culture is conveniently used as part of the visual and sensory backdrop in the messages used to sell many of the products that citizens consume.

D. Contributes to street crime. A number of studies that this paper touches on include the possibility that street culture is a causal factor in the commission of street crime; and, finally.

E. Affects the commission of street violence. When we examine the connection between street crime and street culture, a disproportionate amount of it appears to violent crime.

\section{Literature review/previous attempts to explain street culture}

Over time, due to a constellation of factors, each human entity in the world develops their own unique culture. This is true for groups, corporations, nations, and states alike. One of the areas where culture has been explored is cities (e.g., Mumford, 1938/2016; Zukin, 1995). Many social scientists have recognized that each city has certain norms that develop in terms of dress, habits, and speech that define its urban culture, and that these do not exist in a vacuum. This process is interchangeably referred to as urban culture (Suttles, 1968; Fox, 2015) and/ or style (Ferrell, 1996). This constellation of behaviors and attitudes can be further divided into overlapping subcomponents, including, but not limited to, ghetto culture (e.g., Hannerz, 1969), youth culture (e.g., Ferrell, 2001), gang culture (e.g., Cohen, 1955; Miller, 1958), and street culture (e.g., Ilan, 2015). Although all types of cultures that exist in the city are interesting - and some more than others are deserving of research and analysis - one of the most under-researched fields is street culture.

Few scholars have attempted to explain street culture. Most of the discussions of this subject and phenomenon have been done in a parenthetical manner in the context of juvenile delinquency and street gangs (e.g., Shaw \& McKay, 1942). Although interesting subjects, both by themselves and combined, these two contexts are not sufficient to explain street culture. Thus, we need to look at selected scholarship that deals, in part, with street culture.

One of the earliest attempts to provide a more encompassing explanation of street culture is Fisher's study (1975). He expresses his difficulty with Wirth (1938), who claimed that all problems with cities could be attributed to urbanism. In many respects, this was a refreshing critique of previous commentaries that catalogued the evils of urban life in America and beyond. However, this explanation did not really touch

\footnotetext{
${ }^{12}$ See selected chapters in Richardson \& Skott-Myhre, (2012) that touch on this issue.

${ }^{13}$ Sports merchandising has been able to thrive off of street culture because individuals use the names of teams they identify with as a way to express and connect with each other (Ilan, 2015). Moreover, one can see trends with jerseys or hats that have their roots in street culture and make their way to the mainstream culture. A lot of people from the ghettos use professional sports as aspirational, as something to reach for. For them, success in this industry may be perceived as a ticket out of poverty.
} 
on street culture.

Over the past seventy-five years, however, a number of important ethnographies of American street gangs (e.g., Jankowski, 1991; Venkatesh, 2008), urban subcultures (e.g., Cohen, 1972/2011; Ferrell, 1996, 2001; Duneier, 1999), and/or ghetto/impoverished areas in American cities (Anderson, 1978, 1990/2013, 2000; Bourgois, 2003; Contreras, 2013; Fleisher, 1995; Liebow, 1967/2003; Rios, 2011; Whyte, 1943) have been conducted. ${ }^{14}$ Parallel studies have been done in other countries. For example, in England, well-cited research has been done on street gangs (e.g., Bennett \& Holloway, 2004). Other scholars have investigated street gangs in Europe (e.g., Decker \& Weerman, 2005) and Latin America (e.g., Jones, 2009).

Although some academics (e.g., Sandberg, 2008b, pp. 154-155) have asserted that street culture is synonymous with the study of gangs, there are problems with this approach. ${ }^{15}$ Gangs may embody street culture, but they are not the only groups that utilize street culture.

Closely related to this work is the scholarship on neighborhood effects (e.g., Mayer \& Jencks, 1989; Sampson, 2012; Sharkey \& Faber, 2014). This concept argues that the type of neighborhood has an impact on the individuals who live there. For example, Wilson (1987) suggests that living in poor neighborhoods affects the ability to secure jobs and work outcomes, exposure to and victimization by violence, and physical and mental health outcomes. This body of work, however, does not incorporate the street culture concept.

Although this research is important and sheds light on the street culture experience, it does not specifically focus on the role of street culture as a causal factor. Moreover, most of these explanations are good at describing selected elements of street culture, but they provide only partial understandings. They also approach street culture in a tangential manner. More specifically, no one has developed a theory or model of street culture. The closest anyone has come to providing an indepth explanation of street culture is Ilan (2015). What does Ilan say? He outlines a "The Street Cultural Spectrum" (p. 11), which

explains how street culture variously manifests: as a driver of criminality and expressivity in contexts of urban poverty, or as practices deployed consciously or unconsciously, either to coexist with street cultural adherents or as a means of signifying "cool" that can be bought and sold out of context. The spectrum's qualities can be explained through an analysis of neoliberal globalization which has placed particular pressures on the urban poor, stripped away many routes towards meaningful inclusion, bolstered the significance of the consumer culture and contributed to a politics of exclusion and criminalization. (p. 19)

Ilan reviews a considerable amount of research on street crime and aspects of street culture, but the street culture continuum idea is not really problematized in his book and, thus, is currently limited as an explanatory tool. What is clearly needed is a more comprehensive explanation. Perhaps a model that is dynamic and heuristic in nature will assist us in better understanding street culture.

In short, although anthropologists, criminologists, sociologists, and urban studies scholars, have examined the complexity of street culture, their findings tend to be atomistic and unintegrated. They lack a layering of different explanations of the street, one that evokes the confluence of contributing factors to the urban street. It is not clear why this is the case. However, I suspect this situation exists because of the complex nature of this subject matter.

\footnotetext{
${ }^{14}$ This list is intended to be illustrative and not exhaustive. Also, the works cited do mention "cognate" areas that other authors in this list delve into. See Wacquant's (2002) interesting critique of Duneier's Sidewalk and Anderson's Code of the Street. In general, he has difficulties with these books for romanticizing the values of dignity and respect amongst the urban poor in America. Although Wacquant includes a review of Newman's No Shame in my Game, that book does not examine street culture.

${ }^{15}$ Most importantly, gang activity is increasingly occurring outside of the streets and the back alleys of our inner cities.
}

\section{Why is developing a model of street culture important?}

The social sciences have different methods to prove the existence of a concept. Models provide unique advantages. In general, they allow us to better understand the areas that street culture has an impact. A model will help rationalize the process in order to better explicate the relationship among diverse contributing factors operating in a situation. Over time, the model can be modified to better explain what is occurring or what has taken place. It will allow us to better understand what is going on. This approach is the foundation for the creation of sophisticated empirical models necessitating the collection of data and testing of relationships among variables (e.g. Ritchey, 2012; Sokolowski \& Banks, 2009). This article argues that characterizations of street culture to date have been too narrow and that the concept has wider applicability to urban processes, including urban studies, urban anthropology, and urban geography.

\section{Outlining the dynamic process model of street culture}

In order to sketch out a model of street culture, I integrate three types of influences: primary, secondary, and intersectional ${ }^{16}$. In the spirit of parsimony, the model does not and should not engage each of the subcomponents in depth. It purposely has the feel of an outline, making it amenable for further testing and refinement.

\subsection{A. Primary influences}

To begin with, street culture is dynamic, and varies based on the types of participant/actor, location, and time period in which it is located.

Participants/Actors. The street is occupied by panoply of participants/ actors. From the retail merchant, to the street vendor, to the tourist, to the homeless person, these are all individuals who spend a considerable amount of time on the street and who have their own occasionally complementary or competing objectives for traversing and/or remaining in this location. One of the most dominant actors on the street are the urban poor, sometimes disparagingly referred to as the dangerous classes. In order to negotiate the space and boundaries ${ }^{17}$ inherent within the street, street actors may dress a certain way and interact differently than they might in other contexts (Lauger, 2014).

Another cross-cutting concept is the difference between formal and informal sectors of society. Clearly, people on the street must contend with formal actors such as agents of social control (e.g., the police, social workers, religious leaders, etc.) and economic entities (retail stores, etc.), but they may also be part of an informal sector, such as drug dealers, street vendors, etc. (Cross, 2000; Duneier, 1999; Sampson \& Raudenbush, 1999). ${ }^{18}$ Street culture affects numerous swaths of people, but perhaps the most important are teenagers and young adults. In general, we are talking about people between the ages of 13 and 35. In other words, although seniors may work, walk, and live beside the streets of any particular urban locale, street culture is normally associated with the segment of the population previously identified.

Locations. Street culture is predominantly an urban phenomenon. Yes, streets exist in the suburbs and in small towns, but I am more specifically referring to streets that exist in cities. Finally, this explanation is mainly rooted in the United States, but with certain modifications/adaptations, it can be applied to other advanced industrialized democracies.

Time Periods. Although understanding street culture over history is

\footnotetext{
${ }^{16}$ Some of these ideas intersect with Mears and Kahan (1998).

17 See, for example, the body of work on urban space (e.g., Lefebvre, 1974/1991; Whyte, 1980).

${ }^{18}$ Something to keep in mind: "Neighborhoods vary with respect to the types of role models and peers they provide, the relative sock of various resources and support available to young people ... and the presence of poverty, drugs, and violence" (Sharkey, 2006, pp. 827-828).
} 
interesting and important, contemporary street culture is most relevant to many important trends operating in today's society. Elements from popular culture are drawn from street culture and reproduced in street culture. Although there are some historical approaches to street culture (e.g., Goodman, 1979), their immediate relevance to today's street crime is limited.

In general, there are probably a variety of different street cultures, in the same city, country, and among states.

\subsection{B. Secondary influences}

Also important is the fact that street culture is mediated by images, symbols, fashions, and styles.

In general, it stands to reason that street culture is more than likely interpreted differently by a number of factors, including age, gender, residency, and race/ethnicity between and among residents and outsiders to the city. This variation is based on geography, and the composite factors of race, ethnicity, age, and gender. Residents' views may vary based on their mobility patterns, including what part of the city they live in, where they work, and whom they choose or are forced to interact with. Outsiders, on the other hand, typically garner their impressions about a city via the products of popular culture that are disseminated through cultural industries (e.g., television series, fashion, news media, movies, etc.).

Running through this discourse is a perception of abnormality or "adaptations to deprivation," as if to imply that something is "wrong" with street folks (e.g., Sampson \& Wilson, 1995), oppositional cultures, etc.

\subsection{The major intersectional components}

In general, there are five major components that affect street culture, and street culture, in turn, influences several factors, including how street culture is learned or passed on. Undoubtedly, in any big city, there are numerous transmission belts for street culture. Berg and Stewart (2012), characterizing Harding (2010), say that "adolescents in disadvantaged neighborhoods are exposed to a diversity of contradictory cultural models, meaning that their cultural repertoire is constructed from a broader range of frames from which they can select styles of behavior. It is probable that youths from these neighborhoods will come into contact with a wide array of lifestyles" (p. 383). More specifically, I believe that the major influences on street culture and those that it affects include street capital, competing cultural influences, mass media, social media, and street crime. On the surface, these terms and the processes they refer to seem straight forward, but they do warrant explanation.

First, street capital consists of a unique combination of four principal components that individuals possess: race/ethnicity, gender, reputation, and the related processes of street efficiency/literacy/savvy/ smarts/wisdom. The gender of the person on the street is an important contributor to the outward appearance and perceptions of those with whom they come into contact (Lobo de la Tierra, 2016). Men are definitely at an advantage (Bourgois, 2003; Mullins, 2006). By physical size and strength or by factors associated with them, like aggressivity, men are usually able to prevail when they encounter difficult situations on the street (e.g., Grundetjern \& Sandberg, 2012). Reputation is something that is usually achieved through acts of violence (Ilan, 2015; Zdun, 2008). Finally, street efficiency/literacy/savvy/smarts/wisdom is another factor that allows people to negotiate the complex system of the street. Street efficiency is the "perceived ability to avoid violent confrontations and to be safe in one's neighborhood" (Sharkey, 2006, p. 826). Street literacy refers to "a conceptual framework that describes the dynamic process of experiential knowledge production and selfconstruction in a specified context public urban space" (Cahill, 2000, p. 251). Closely related are the concepts of street smarts and street wisdom. According to Anderson (1990/2013), street smarts and street wisdom are the ways people carry themselves on the street in order to minimize victimization. He adds, "In these circumstances the person neither takes the streets for granted, or recoils from them but becomes alive to dangerous situations, drawing on a developing repertoire of ruses and schemes for travelling the streets safely. In a word, the person learns street sense, how to behave in a sensible manner" (p. 6). Others, like Dance (2002), prefer the term street-savvy to basically explain the same thing. ${ }^{19}$ All three of these processes (i.e., gender, reputation, and street literacy/smarts/wisdom) are intimately connected to each other. This concept is also equivalent to street efficacy (Sharkey, 2006), but this idea (i.e., street efficiency/literacy/savvy/smarts/wisdom) is primarily used to describe how adolescents negotiate the challenges they experience on the streets of their neighborhood or community.

Second, also important for street culture are competing cultural influences that a person experiences and/or to which they are exposed. By this I mean the relative effects of formal and informal social control. In anyone's life, their parents, guardians, friends, teachers, and other significant people, like their close relatives, etc., may impact them. On the street, the shopkeeper, the policeman, the school crossing guard, etc. may act as positive or negative role models, and either overtly or covertly influence a person's behavior. This shaping can be in the direction of something good or bad. Sociology likes to call these people and institutions formal and informal agents of social control. Many of the outcomes have to do with the powerful effects of socialization. For example, in order to fit in because of peer pressure, and/or conformity, participants often conform to mores and ways of the street. Few people want to be left out of a relevant and important social group whose values and/or objectives they believe in (Sutherland, 1949). That is why the power of gangs is important in this context. Also relevant is the symbiotic relationship between popular culture and street culture in cities (e.g., Ilan, 2015). This occurs through a complicated and subtle process that reinforces the idea of the other. Although elements of popular culture may not directly generate street culture in any particular location, they certainly shape it. Many elements in society want and have an impact on people, including religious institutions, school, and the police, but one cannot ignore the powerful effects of popular culture.

Third, the mass media and cultural industries (e.g., Schiller, 1989) exert extraordinary power on many sectors of society. Both of these collectivities of institutions consist of numerous different types of organizations, including newspapers, radio and television stations, museums, etc. Relevant to these processes are the actors' ability to access these. Not all urban dwellers, for example, may be able to afford admission to a museum or gallery, and as a result, see it as a luxury. Poor people, because of competing demands, may not have the time to visit on the days and times when entrance is free to the public. Although popular culture and the cultural industries such as the mass media, may serve as a transmission belt, other processes can be at work. For example, among a criminal subculture, correctional facilities may also play a part (act as a transmission belt), where norms related to dress, language, and behavior are added to the mix. When individuals are released from jails and prisons, they bring these components back to their communities/neighborhoods, where they are integrated into street style and street culture (e.g., Irwin \& Cressey, 1962).

Fourth, social media, especially the utilization and consumption thereof, is also relevant because the number of youth on social media is staggering. Whether we are talking about Facebook, Instagram, SnapChat, or Twitter, today's youth consume a considerable amount of messages, ideas, and images in this manner. This contributes to wants, desires, and a proclivity towards consumerism (Hayward, 2004). In terms of scholarly attention, the majority of research on the connection

\footnotetext{
${ }^{19}$ Dance "prefer(s) the term 'street savvy' over the expression 'streetwise' because 'wise' when applied to urban youth from low income communities may conjure up images of youths who are 'wise guys' or 'wise' in the pejorative sense" (p. 2-3). Dance does not consider street smarts or wisdom as terms.
} 


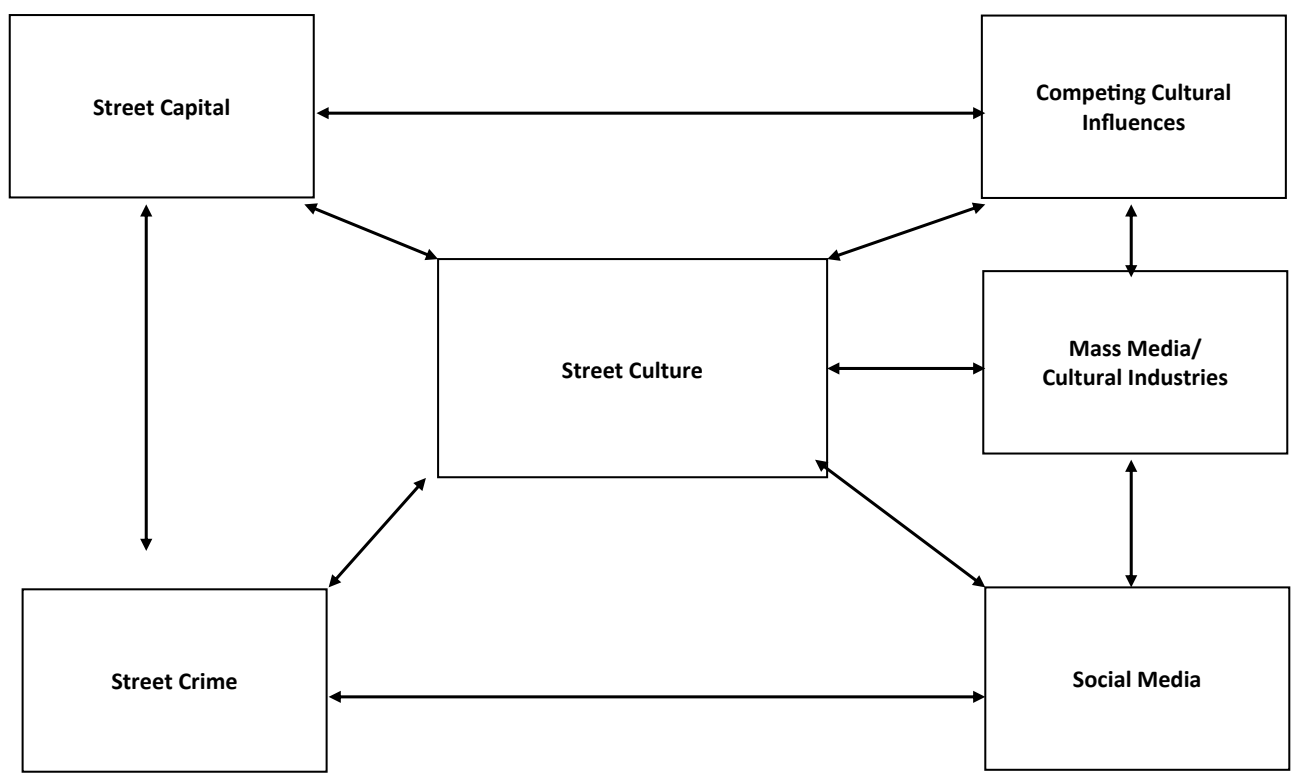

Fig. 1. A Dynamic Process Model of street culture.

between social media and street culture has been conducted in the context of the 2011 London riots and the activity of gang members in various jurisdictions. Through cell and smartphone technology, friends, associates, and enemies can keep in touch through a complex electronic network. Messages, threats, and admonishments can be made, glossed over, or acted on in a behavioral sense via social media. Social media helps networks keep in touch (Patton, Eschmann, \& Butler, 2013; Patton et al., 2014).

Finally the factor of street crime is very dominant in the street culture process (Ross, 2013). Street culture is best seen as both a cause and an effect of street crime. To begin with, many processes, and a handful of explanations and theories have been articulated that outline the causes of street crime. Individual causal factors may include opportunity, lack of alternatives, and societal pressures, including systemic racism, oppression, and poverty. By the same token, although street crime can be a direct consequence of street culture, street culture can exist without street crime.

A deeper understanding of the role of street culture and crime is warranted. Silverman (2004), for example, states that most violent crimes that take place in urban ghettos are not done for "pecuniary motivations." In fact, most financial gains that are achieved through street robbery (a type of violent street crime) are seen as unexpected (pp. 763-764). Similarly, Ilan (2015) notes that many young men engage in street crimes, not for financial gain, but to demonstrate to their peers and others some sort of hierarchy or territorial dominance, and to fill up their leisure time (p. 95). This admonition is similar to Katz (2008), who suggests that street crime is often done for the thrill and excitement, rather than the monetary gain to be accrued by participants. $^{20}$

We also know that particular attitudes are transmitted to and from individuals who engage in criminal activity (Krohn, 1986). One explanation of this process is rooted in neutralization theory (Sykes \& Mazda, 1957). This explains how and why, for example, criminals succumb to "scripts" in order to justify the crimes they engage in. In many respects, Sutherland's theory of differential association also supports this idea (Sutherland, 1949). But the scripts are learned somewhere, often on the streets and in the back alleys of our urban centers.

The previously reviewed components are dynamic and do not exist

20 Other interpretations on the role of violence in street culture are available, but not explained here as their relevance is more connected to street capital. in a vacuum. They interact with each other in complex ways. The figure below (Fig. 1) outlines these most dominant components and some possible connections among them in terms of directionality. ${ }^{21}$

\section{Conclusion}

In the field of criminology/criminal justice, much of the focus is on street crime, corrections, policing, and juvenile justice. These subjects are important building blocks to understand street culture, but they are only partial explanations. Given the relevance of street culture to numerous aspects of contemporary culture and commerce, it is curious that so little attention has been spent on defining, understanding, and explaining this process. This is particularly relevant for the scholarly fields of urban studies, urban geography, and urban anthropology. In other words, the concept and process of street culture has wider applicability beyond the field of criminology/criminal justice than currently exists. The previously articulated model should assist those interested in this topic to better understand what transpires.

Another aspect that is minimally explored is the role of street culture in the health, stability, and vibrancy of urban life. City leaders, administrators, urban planners, and urban dwellers must be mindful of the uniqueness of different neighborhoods, that a one size fits all approach to providing city services and assisting the local economy, and the safety and security of its citizens is not wise. Moreover, the uniqueness of different neighborhoods should be appreciated, and not simply be interesting and iconic establishing shots for attracting tourists and visual artists.

So where do we go from here? Although street culture is important to study on its own, it is perhaps more interesting and relevant to tie street culture to specific places where it originates. It is important to apply this model to an appropriate setting or situation. Covering a whole city would be difficult, but not impossible. Relevant ethnographic research focusing on a particular neighborhood, and/or block in a city over a meaningful period of time would be even more expeditious. This could include interviews and observational work not only with youth, juveniles, and youth gangs, but also with social workers, street workers, shopkeepers, street vendors, and seniors. When this is accomplished, further nuances of this model can be fleshed out,

\footnotetext{
${ }^{21}$ Future iterations of this model will attempt to tease out the relationship among these concepts.
} 
and hypotheses can be generated for future testing.

Connected to this effort will be a necessity to operationalize the concepts reviewed in this article, which may lead to some modifications of the model. Inevitably, the application of the concepts developed in this model to case studies may allow for additional refinement of the model.

\section{Acknowledgements}

Special thanks to the editor and anonymous reviewers of this journal who offered comments on earlier versions of this paper. Appreciation also extended to Rachel Hildebrandt for comments, and to Vickie Sneed for revising multiple versions of the figure.

\section{Appendix A. Supplementary data}

Supplementary data related to this article can be found at http://dx. doi.org/10.1016/j.ccs.2018.05.003.

\section{References}

Abrahamson, M. (1974). The social dimensions of urbanism. Social Forces, 52(3), 76-84. Anderson, E. (1978). A place on the corner. Chicago: University of Chicago Press. Anderson, E. (1990/2013). Street Wise: Race, class, and change in an urban community chicago. Chicago: University of Chicago Press.

Anderson, E. (2000). Code of the street: Decency, violence, and the moral life of the inner city. New York: WW Norton \& Company.

Baron, S. W. (1989). Resistance and its consequences: The street culture of punks. Youth \& Society, 21(2), 207-237.

Bennett, T., \& Holloway, K. (2004). Gang membership, drugs and crime in the UK. British Journal of Criminology, 44(1), 305-323.

Berg, M. T., \& Stewart, E. A. (2012). Street culture and crime. In F. Cullen, \& P. Wilcox (Eds.). The oxford handbook of criminological theory (pp. 370-388). New York, NY: Oxford University Press.

Biaya, T. K. (2005). Youth and street culture in urban Africa addis ababa, dakar and kinshasa. Makers and Breaker: Children and youth in postcolonial Africa. Oxford: James Currey.

Bourdieu, P. (1977). Outline of a theory of practice. Cambridge: Cambridge University Press.

Bourgois, P. (2003). In search of Respect: Selling crack in El barrio (2 ${ }^{\text {nd }}$ ed.). Cambridge: Cambridge University Press.

Cahill, C. (2000). Street literacy: Urban teenagers' strategies for negotiating their neighbourhood. Journal of Youth Studies, 3(3), 251-277.

Campbell, S., \& Fainstein, S. S. (Eds.). (2011). Readings in urban planning(3rd ed.). Malden, MA: Wiley-Blackwell.

Cohen, A. K. (1955). Delinquent Boys: The culture of the gang. New York: Free Press.

Cohen, S. (1972/2011). Folk devils and moral Panics: The creation of the mods and rockers. New York, NY: Routledge Press.

Contreras, R. (2013). The stickup Kids: Race, drugs, violence, and the american dream. Berkeley, CA: University of California Press.

Cross, J. (2000). Street vendors, and postmodernity: Conflict and compromise in the global economy. International Journal of Sociology \& Social Policy, 20(1/2), 29-51.

Dance, L. J. (2002). Tough fronts: The impact of street culture on schooling. Hove, UK: Psychology Press.

Decker, S. H., \& Weerman, F. M. (Eds.). (2005). European street gangs and troublesome youth groups. AltaMira Press.

Duneier, M. (1999). Sidewalk. New York: Farrar, Strauss, and Giroux.

Fainstein, S., \& Campbell, S. (Eds.). (2011). Readings in urban theory(3rd ed.). Malden, MA: Wiley-Blackwell.

Ferrell, J. (1996). Crimes of style. Boston, MA: Northeastern University Press.

Ferrell, J. (2001). Tearing down the Streets: Adventures in urban anarchy. New York: St. Martin's Press.

Fischer, C. (1975). Toward a subcultural theory of urbanism. American Journal of Sociology, 80(6), 1319-1341.

Fleisher, M. S. (1995). Beggars and Thieves: Lives of urban street criminals. Madison: University of Wisconsin Press.

Fox, R. G.. Urban culture. Encyclopedia Britannica on-line. (2015). http://britanica.come/ topic/urbanculture downloaded April 23, 2017.

Goffman, E. (1956). The presentation of self in Everyday life. New York: Anchor Books.

Goffman, E. (1967). Interaction ritual. Chicago: Aldine.

Goodman, C. (1979). Choosing sides: Playground and street life on the lower East side. New York: Schocken Books.

Grundetjern, H., \& Sandberg, S. (2012). Dealing with a gendered economy: Female drug dealers and street capital. European Journal of Criminology, 9(6), 621-635.

Hannerz, U. (1969). Soulside: Inquiries into ghetto culture and community. Chicago: University of Chicago Press.

Harding, D. (2010). Living the Dream: Community, conflict, and culture among inner city boys. Cambridge, MA: Harvard University Press.

Hayward, K. (2004). City Limits: Crime, consumer culture and the urban experience. London: Glass House Press.
Ilan, J. (2015). Understanding street Culture: Poverty, crime, youth and cool. London, UK: Palgrave.

Irwin, J., \& Cressey, D. R. (1962). Thieves, convicts and the inmate culture. Social Problems, 10(2), 142-155.

Jacobs, J. (1961). The death and life of great american cities. New York: Random House.

Jankowski, M. S. (1991). Islands in the Street: Gangs and american urban society. Berkeley, CA: University of California Press.

Jones, G. (Ed.). (2009). Youth violence in Latin America: Gangs and juvenile justice in perspective. Springer.

Katz, J. (2008). Seductions of crime: Moral and sensual attractions in doing evil. New York, NY: Basic Books.

Krohn, M. (1986). The web of conformity: A network approach to the explanation of delinquent behavior. Social Problems, 33(6), 581-593.

Lauger, T. R. (2014). Violent stories personal narratives, street socialization, and the negotiation of street culture among street-oriented youth. Criminal Justice Review, 39(2), 182-200.

Lefebvre, H. (1974/1991). The production of space. Oxford: Blackwell.

Lewis, O. (1968). A study of slum Cultures: Backgrounds for La vida. New York: Random House.

Liebow, E. (1967/2003). Tally's corner: A study of Negro street corner men. Lanham, MD: Rowman \& Littlefield.

Lind, A. W. (1930). The ghetto and the slum. Social Forces, 9(1), 206-215.

Lobo de la Tierra, A. (2016). Essentializing manhood in "the Street": Perilous masculinity and popular criminological ethnographies. Feminist Criminology, 11(4), 375-397.

Matthews, H. (2003). The street as liminal space: The barbed wire of childhood. In P. Christensen, \& M. O'Bien (Eds.). Children in the city: Home, neighbourhood and community (pp. 101-117). London: Routledge.

Mayer, S. E., \& Jencks, C. (1989). Growing up in poor Neighborhoods: How much does it matter? Science, 243, 1441-1445.

Mears, T. L., \& Kahan, D. M. (1998). Law and (norms of) order in the inner city. Law \& Society Review, 32(4), 805-838.

Miller, W. B. (1958). Lower class culture as a generating milieu of gang delinquency. Journal of Social Issues, 14(3), 5-19.

Mullins, C. W. (2006). Holding your Square: Masculinities, street life and violence. Cullompton, Devon: Willan.

Mumford, L. (1938/2016). The culture of cities. San Diego, CA: Harvest Books.

Patton, D. U., Eschmann, R. D., \& Butler, D. A. (2013). Internet banging: New trends in social media, gang violence, masculinity and hip-hop. Computers in Human Behavior, 29(5), A54-A59.

Patton, D. U., Hong, J. S., Ranney, M., Patel, S., Kelley, C., Eschmann, R., Washington, T., et al. (2014). Social media as a vector for youth violence: A review of the literature. Computers in Human Behavior, 35, 548-553.

Pavis, S., \& Cunningham-Burley, S. (1999). Male youth street culture: Understanding the context of health-related behaviours. Health Education Research, 14(5), 583-596.

Polhemus, T. (2010). Streetstyle. London: Pymca.

Richardson, C., \& Skott-Myhre, H. A. (Eds.). (2012). Habitus of the hood. Chicago, IL: Intellect.

Rios, V. (2011). Punished: Policing the lives of black and latino boys. New York, NY: New York University Press.

Ritchey, T. (2012). Contribution to a general theory of modeling. Acta Morphologica Generalis, 1(10), 1-20.

Ross, J. I. (Ed.). (2013). Encyclopedia of street crime in America. Thousand Oaks, CA: Sage Publications.

Ross, J. I. (Ed.). (2016). Routledge handbook on graffiti and street art. New York: Routledge Publishers.

Sampson, R. J. (2012). Great american city. Chicago, IL: University of Chicago Press.

Sampson, R. J., \& Raudenbush, S. W. (1999). Systematic social observation of public spaces. American Journal of Sociology, 105(2), 603-651.

Sampson, R. J., \& Wilson, W. J. (1995). Toward a theory of race, crime, and urban inequality. In John Hagan, \& Ruth D. Peterson (Eds.). Crime and inequality (pp. 37-56). Stanford, CA: Stanford University Press.

Sandberg, S. (2008a). Street capital: Ethnicity and violence on the streets of Oslo. Theoretical Criminology, 12(2), 153-171.

Sandberg, S. (2008b). Black drug dealers in a white welfare state: Cannabis dealing and street capital in Norway. British Journal of Criminology, 48(5), 604-619.

Sandberg, S., \& Pedersen, W. (2009). Street capital: Black cannabis dealers in a white welfare state. Bristol: Policy Press.

Savage, V. R. (1992). Street culture in colonial Singapore. In B. H. Chua, \& E. Norman (Eds.). Public Space: Design, use and management (pp. 11-23). Singapore: Singapore University Press.

Schiller, H. (1989). Culture Inc., the corporate takeover of public expression. New York: Oxford University Press.

Sharkey, P. (2006). Navigating dangerous streets: The Sources and consequences of street efficacy. American Sociological Review, 71(5), 826-846.

Sharkey, P., \& Faber, J. (2014). Where, When, Why and for Whom do Residential Contexts Matter? Moving away from the dichotomous understanding of neighborhood effects. Annual Review of Sociology, 40, 559-579.

Shaw, C., \& McKay, H. (1942). Juvenile delinquency and urban areas. Chicago, IL: University of Chicago Press.

Silverman, D. (2004). Street crime and street culture. International Economic Review, 45(3), 761-786.

Sokolowski, J. A., \& Banks, C. M. (2009). Principles of modeling and simulation. Hoboken, NJ: Wiley.

Sutherland, E. (1949). Criminology (4 ${ }^{\text {th }}$ ed.). Philadelphia, PA: J.B. Lippincott.

Suttles, G. D. (1968). The social order of the Slum: Ethnicity and territory in the inner city. Chicago, IL: University of Chicago Press. 
Sykes, G. M., \& Mazda, D. (1957). Techniques of neutralization: A theory of delinquency. American Sociological Review, 22(6), 664-670.

Venkatesh, S. (2008). Gang leader for a day. New York, NY: Penguin Books.

Wacquant, L. (2002). Review Symposium: Scrutinizing the Street: Poverty, morality, and the pitfalls of urban ethnography. American Journal of Sociology, 107(6), 1468-1532.

Whyte, W. F. (1943). Street corner society. Chicago, IL: University of Chicago Press.

Whyte, W. H. (1980). The social life of small urban spaces. New York, NY: Project for Public Spaces.
Wilson, W. J. (1987). The Truly disadvantaged: The inner city, the underclass, and public policy. Chicago: University of Chicago Press.

Wirth, L. (Ed.). (1928/1997). The ghetto. New Brunswick, NJ: Transaction Publishers.

Wirth, L. (1938). Urbanism as a way of life. American Journal of Sociology, 44(1), 3-24.

Zdun, S. (2008). Violence in street culture: Cross-cultural comparison of youth groups and

criminal gangs. New Directions for School Leadership, 119, 39-54 (?).

Zukin, S. (1995). The cultures of cities. Oxford: Blackwell. 